\title{
Assessment of the effects of sulfate and nitrate on the temporal evolution of Klebsiella oxytoca and Staphylococcus aureus abundance under shaking conditions, in aquatic microcosm Évaluation de l'influence du nitrate et du sulfate sur l'évolution temporelle d'abondance de Klebsiella oxytoca et Staphylococcus aureus sous conditions agitées en milieu aquatique en microcosme
}

\author{
Moïse Nola, Robert Roger Nlep, Pierre Servais, Norbert Kemka, Serge H. Zebaze \\ Togouet,, François Krier, Nour-Eddine Chihib, Jean-Pierre Hornez et Thomas \\ Njine
}

Volume 23, numéro 3, 2010

URI : https://id.erudit.org/iderudit/044685ar

DOI : https://doi.org/10.7202/044685ar

Aller au sommaire du numéro

\section{Éditeur(s)}

Université du Québec - INRS-Eau, Terre et Environnement (INRS-ETE)

ISSN

0992-7158 (imprimé)

1718-8598 (numérique)

Découvrir la revue

Citer cet article

Nola, M., Nlep, R. R., Servais, P., Kemka, N., Zebaze Togouet,, S. H., Krier, F., Chihib, N.-E., Hornez, J.-P. \& Njine, T. (2010). Assessment of the effects of sulfate and nitrate on the temporal evolution of Klebsiella oxytoca and Staphylococcus aureus abundance under shaking conditions, in aquatic microcosm. Revue des sciences de l'eau / Journal of Water Science, 23(3), 197-212.

https://doi.org/10.7202/044685ar

\section{Résumé de l'article}

L'impact de diverses conditions environnementales sur l'assimilation bactérienne dans l'eau, des composés chimiques est peu connu. La présente étude a visé l'évaluation de la dynamique d'abondance de Klebsiella oxytoca et Staphylococcus aureus sous diverses conditions, en milieu aquatique microcosme contenant du sulfate ou nitrate. Des solutions du $\mathrm{NaCl}\left(8,5 \mathrm{~g} \cdot \mathrm{L}^{-1}\right)$, sulfate et nitrate $\left(0,005,0,05,0,5\right.$ et $\left.5 \mathrm{~g} \cdot \mathrm{L}^{-1}\right)$ contenant des cellules ont été enrichies à la peptone trypsique (concentration finale $10 \mathrm{~g} \cdot \mathrm{L}^{-1}$ ), puis incubées sous conditions dynamiques ( 300,350 et $400 \mathrm{tr}^{\bullet} \mathrm{min}^{-1}$ ). Les analyses bactériologiques ont été effectuées pendant $6 \mathrm{~h}$. Il ressort qu'au cours des trois premières heures d'incubation, le taux de croissance cellulaire apparent (TCCA) le plus élevé en culture pure, contenant du $\mathrm{K}_{2} \mathrm{SO}_{4}$, est de $0,656 \mathrm{~h}^{-1}$ pour $S$. aureus, et $0,364 \mathrm{~h}^{-1}$ pour $K$. oxytoca, enregistrés à $400 \mathrm{tr} \bullet \mathrm{min}^{-1}$. En culture mixte, il est de $0,235 \mathrm{~h}^{-1}$ pour $S$. aureus, et $0,388 \mathrm{~h}^{-1}$ pour $K$. oxytoca, enregistrés à 300 tr $\bullet \mathrm{min}^{-1}$. Avec du KNO ${ }_{3}$, en culture pure, le TCCA est de $0,353 \mathrm{~h}^{-1}$ pour $S$. aureus à 300 tr•min ${ }^{-1}$, et $0,367 \mathrm{~h}^{-1}$ à $350 \mathrm{tr}^{\bullet} \mathrm{min}^{-1}$ pour $K$. oxytoka. En culture mixte, il est de $0,454 \mathrm{~h}^{-1}$ pour $S$. aureus et $0,393 \mathrm{~h}^{-1}$ pour $K$. oxytoca, enregistrés à 350 tr•min ${ }^{-1}$. Le taux d'inhibition cellulaire apparent (TICA) le plus élevé de $S$. aureus est de $0,520 \mathrm{~h}^{-1}$ en présence du $\mathrm{K}_{2} \mathrm{SO}_{4}\left(5 \mathrm{~g} \bullet \mathrm{L}^{-1}, 400 \mathrm{tr} \bullet \mathrm{min}^{-1}\right)$, et $0,115 \mathrm{~h}^{-1}$ en présence de $\mathrm{KNO}_{3}\left(5 \mathrm{~g} \cdot \mathrm{L}^{-1}, 300 \mathrm{tr} \bullet \mathrm{min}^{-1}\right)$. Pour $K$. oxytoca, il est de $0,07 \mathrm{~h}^{-1}$ avec du $\mathrm{K}_{2} \mathrm{SO}_{4}$ en culture pure $\left(0,05 \mathrm{~g} \mathrm{~L}^{-1}, 300 \mathrm{tr}^{-1} \mathrm{~min}^{-1}\right)$, et $0,044 \mathrm{~h}^{-1}$ en culture mixte $\left(0,05 \mathrm{~g} \cdot \mathrm{L}^{-1}, 350 \mathrm{tr} \cdot \mathrm{min}^{-1}\right)$. Avec du $\mathrm{KNO}_{3}$, il est de $0,239 \mathrm{~h}^{-1}$ en culture mixte $\left(5 \mathrm{~g} \cdot \mathrm{L}^{-1}, 300 \mathrm{tr} \bullet \mathrm{min}^{-1}\right)$. La croissance et l'inhibition des microorganismes sont affectées par les concentrations en sels et la vitesse de mouvements du milieu. 


\section{ASSESSMENT OF THE EFFECTS OF SULFATE AND NITRATE ON THE TEMPORAL EVOLUTION OF KLEBSIELLA OXYTOCA AND STAPHYLOCOCCUS AUREUS ABUNDANCE UNDER SHAKING CONDITIONS, IN AQUATIC MICROCOSM}

Évaluation de l'influence du nitrate et du sulfate sur l'évolution temporelle d'abondance de Klebsiella oxytoca et Staphylococcus aureus sous conditions agitées en milieu aquatique en microcosme

Moïse NOL $A^{1, *}$, Robert Roger NLEP', PIERre SERVAIS ${ }^{2}$, Norbert KEMKA', SERge H. ZEBAZE TOGOUET', FranÇOIS KRIER 3 , NOUR-EDDINE CHIHIB ${ }^{3}$, JEAN-PIERRE HORNEZ ${ }^{3}$ aNd THOMAS NJINE ${ }^{1}$

\footnotetext{
${ }^{1}$ University of Yaounde 1, Faculty of Sciences, Laboratory of General Biology, P.O. Box 812, Yaounde, Cameroon. ${ }^{2}$ Université Libre de Bruxelles, Écologie des Systèmes Aquatiques, Campus de la Plaine, CP 221, Boulevard du Triomphe, 1050 Bruxelles, Belgique.

${ }^{3}$ Université des Sciences et Technologies de Lille 1, IUT «A », Département de Génie Biologique, Laboratoire ProBioGEM, Boulevard Paul Langevin, Cité Scientifique, B.P. 179, 59655 Villeneuve d'Ascq cedex, France.
}

Reçu le 19 juin 2009, accepté le 23 octobre 2009

\section{ABSTRACT}

Most chemicals in natural aquatic media can be assimilated by bacteria. The impact of various environmental conditions on this microbial process is not always clear. This study aimed at investigating changes in the abundance of Klebsiella oxytoca and Staphylococcus aureus under different shaking conditions, in aquatic microcosms containing nitrate and sulfate. Sodium chloride solution $\left(8.5 \mathrm{~g} \mathrm{NaCl} \cdot \mathrm{L}^{-1}\right)$, and nitrate and sulfate solutions $\left(0.005,0.05,0.5\right.$ and $\left.5 \mathrm{~g} \bullet \mathrm{L}^{-1}\right)$ containing bacteria were supplemented with tryptic peptone at a final concentration of $10 \mathrm{~g} \bullet \mathrm{L}^{-1}$. The solutions were incubated under shaking conditions (300, 350 and $400 \mathrm{rev} \bullet \mathrm{min}^{-1}$ ). Bacteriological analyses were performed hourly over a 6 -h period. During the first $3 \mathrm{~h}$ of incubation, results showed that the highest values of the apparent cell growth rates (CAGRs) with $\mathrm{K}_{2} \mathrm{SO}_{4}$ in pure cultures, at a shaking speed $400 \mathrm{rev} \bullet \mathrm{min}^{-1}$, were $0.656 \mathrm{~h}^{-1}$ for $S$. aureus, and $0.364 \mathrm{~h}^{-1}$ for $K$. oxytoca. In mixed culture, the CAGR was $0.235 \mathrm{~h}^{-1}$ for $S$. aureus, and $0.388 \mathrm{~h}^{-1}$ for $K$. oxytoca, both recorded at $300 \mathrm{rev} \bullet \mathrm{min}^{-1}$. With $\mathrm{KNO}_{3}$ in pure culture solutions, the CAGR was $0.353 \mathrm{~h}^{-1}$ for $S$. aureus at $300 \mathrm{rev}^{\bullet} \mathrm{min}^{-1}$, and $0.367 \mathrm{~h}^{-1}$ for $K$. oxytoca at $350 \mathrm{rev}^{\bullet} \mathrm{min}^{-1}$. In mixed culture it was $0.454 \mathrm{~h}^{-1}$ for $S$. aureus and $0.393 \mathrm{~h}^{-1}$ for $K$. oxytoca, both recorded at $350 \mathrm{rev}^{\bullet} \mathrm{min}^{-1}$. The highest value of the apparent cell inhibition rate (CAIR)

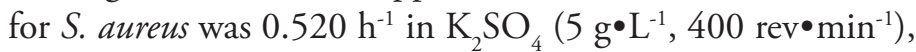
and $0.115 \mathrm{~h}^{-1}$ in $\mathrm{KNO}_{3}\left(5 \mathrm{~g} \bullet \mathrm{L}^{-1}, 300 \mathrm{rev} \bullet \mathrm{min}^{-1}\right)$. For $K$. oxytoca, it was $0.07 \mathrm{~h}^{-1}$ in $\mathrm{K}_{2} \mathrm{SO}_{4}$ in pure culture $\left(0.05 \mathrm{~g} \bullet \mathrm{L}^{-1}\right.$, $\left.300 \mathrm{rev}^{\bullet} \mathrm{min}^{-1}\right)$, and $0.044 \mathrm{~h}^{-1}$ in mixed culture $\left(0.05 \mathrm{~g} \cdot \mathrm{L}^{-1}\right.$, $\left.350 \mathrm{rev}^{\bullet} \mathrm{min}^{-1}\right)$. In $\mathrm{KNO}_{3}$ it was $0.239 \mathrm{~h}^{-1}$ in mixed culture $\left(5 \mathrm{~g} \bullet \mathrm{L}^{-1}, 300 \mathrm{rev} \bullet \mathrm{min}^{-1}\right)$. The growth and inhibition potentials of different microbial species were impacted by the chemical concentrations and the movement speeds.

Key words: aquatic microcosm, shaking, sulfate, nitrate, bacteria evolution. 


\section{RÉSUMÉ}

L'impact de diverses conditions environnementales sur l'assimilation bactérienne dans l'eau, des composés chimiques est peu connu. La présente étude a visé l'évaluation de la dynamique d'abondance de Klebsiella oxytoca et Staphylococcus aureus sous diverses conditions, en milieu aquatique microcosme contenant du sulfate ou nitrate. Des solutions $\mathrm{du} \mathrm{NaCl}\left(8,5 \mathrm{~g} \bullet \mathrm{L}^{-1}\right)$, sulfate et nitrate $(0,005,0,05,0,5$ et $\left.5 \mathrm{~g} \bullet \mathrm{L}^{-1}\right)$ contenant des cellules ont été enrichies à la peptone trypsique (concentration finale $10 \mathrm{~g} \bullet \mathrm{L}^{-1}$ ), puis incubées sous conditions dynamiques $\left(300,350\right.$ et $\left.400 \mathrm{tr} \bullet \mathrm{min}^{-1}\right)$. Les analyses bactériologiques ont été effectuées pendant $6 \mathrm{~h}$. Il ressort qu'au cours des trois premières heures d'incubation, le taux de croissance cellulaire apparent (TCCA) le plus élevé en culture pure, contenant du $\mathrm{K}_{2} \mathrm{SO}_{4}$, est de $0,656 \mathrm{~h}^{-1}$ pour $S$. aureus, et $0,364 \mathrm{~h}^{-1}$ pour $K$. oxytoca, enregistrés à $400 \mathrm{tr} \bullet \mathrm{min}^{-1}$. En culture mixte, il est de $0,235 \mathrm{~h}^{-1}$ pour $S$. aureus, et $0,388 \mathrm{~h}^{-1}$ pour $K$. oxytoca, enregistrés à $300 \mathrm{tr} \bullet \mathrm{min}^{-1}$. Avec du $\mathrm{KNO}_{3}$, en culture pure, le TCCA est de $0,353 \mathrm{~h}^{-1}$ pour $S$. aureus à $300 \mathrm{tr} \bullet \mathrm{min}^{-1}$, et $0,367 \mathrm{~h}^{-1}$ à $350 \mathrm{tr} \bullet \mathrm{min}^{-1}$ pour $K$. oxytoka. En culture mixte, il est de $0,454 \mathrm{~h}^{-1}$ pour $S$. aureus et $0,393 \mathrm{~h}^{-1}$ pour $K$. oxytoca, enregistrés à $350 \mathrm{tr} \bullet \mathrm{min}^{-1}$. Le taux d'inhibition cellulaire apparent (TICA) le plus élevé de $S$. aureus est de $0,520 \mathrm{~h}^{-1}$ en présence du $\mathrm{K}_{2} \mathrm{SO}_{4}\left(5 \mathrm{~g} \bullet \mathrm{L}^{-1}, 400 \mathrm{tr} \bullet \mathrm{min}^{-1}\right)$, et $0,115 \mathrm{~h}^{-1}$ en présence de $\mathrm{KNO}_{3}\left(5 \mathrm{~g} \bullet \mathrm{L}^{-1}, 300 \mathrm{tr}^{\bullet} \mathrm{min}^{-1}\right)$. Pour $K$. oxytoca, il est de $0,07 \mathrm{~h}^{-1}$ avec du $\mathrm{K}_{z} \mathrm{SO}_{4}$ en culture pure $\left(0,05 \mathrm{~g} \bullet \mathrm{L}^{-1}\right.$, $\left.300 \mathrm{tr} \bullet \mathrm{min}^{-1}\right)$, et $0,044 \mathrm{~h}^{-1}$ en culture mixte $\left(0,05 \mathrm{~g} \bullet \mathrm{L}^{-1}\right.$, $\left.350 \mathrm{tr} \cdot \mathrm{min}^{-1}\right)$. Avec du $\mathrm{KNO}_{3}$, il est de $0,239 \mathrm{~h}^{-1}$ en culture mixte $\left(5 \mathrm{~g} \bullet \mathrm{L}^{-1}, 300 \mathrm{tr} \bullet \mathrm{min}^{-1}\right)$. La croissance et l'inhibition des microorganismes sont affectées par les concentrations en sels et la vitesse de mouvements du milieu.

Mots clés : milieu aquatique en microcosme, agitation, sulfate, nitrate, évolution bactérienne.

\section{INTRODUCTION}

Natural aquatic environments harbor many bacterial species and numerous chemicals such as nitrates and sulfates. These chemicals can result from natural processes or from anthropological effects. Nitrates and sulfates can be assimilated by Klebsiella and Staphylococcus (PINAR and RAMOS, 1998). These bacteria can use nitrate and nitrite as sole nitrogen sources during aerobic growth. Nitrate assimilation takes place by three sequential steps: (i) nitrate transport into the cell by a specific nitrate permease; (ii) reduction to nitrite by assimilatory nitrate reductase; and (iii) further reduction to ammonium by assimilatory nitrite reductase. The resulting ammonium is then incorporated into central metabolism through the action of glutamine synthetase and glutamate synthetase (WU and STEWART, 1998). Nitrate sometimes favors the degradation of other compounds such as naphtalene under certain conditions (ROCKNE et al., 1999). Degradation of numerous carbon molecules can be coupled to that of nitrates, but not often to sulfates (BAE et al., 2002).

Most of aerobic aquatic bacteria are known to use assimilatory sulfate reduction to supply sulfur for biosynthesis, although many can assimilate sulfur from organic compounds that contain reduced sulfur atoms (COTTRELL and KIRCHMAN, 2000; TRIPP et al., 2008). The assimilation of sulfate by bacteria is increased at the $\mathrm{pH}$ of the environment close to neutral (REIS et al., 2005). In the presence of oxygen, sulfur metabolism is particularly energy costly. Sulfur and sulfate must first permeate the cell, usually against the intracellular electric potential which is usually strongly negative, then change from a highly oxidized state to a reduced state (SEKOWSKA and DANCHIN, 2009).

The biodegradation of sulfates and nitrates occurs in surface waters as well as during water infiltration through soil columns, and this process is sometimes impacted by the variation in oxygen concentrations in the environment (GANDHI et al., 2002; ZINEBI et al., 1994). Surface waters contain a variety of inorganic compounds and numerous bacterial species. These media are more often in movement. Along their trajectories, the quiet flow sections alternate with the fast ones which are more often agitated and are characterized by turbulence.

Microscopic organisms in aquatic environments are continuously exposed to a variety of physical and chemical conditions. Traditionally, it is accepted that due to their small size the physiology of microscopic organisms is not affected by the moving fluid at their scale (HONDZO and WUEST, 2009). The role of turbulence on the bacterial abundance evolution rate has been assessed by MOESENEDER and HERNDL (1995). They noted that bacterial growth rate is significantly modified by this factor with respect to the substrate. However, little data are available on the impact of this physical parameter when the medium contains the known chemicals and bacteria. Little is known of the impact of nitrates and sulfates on the microbial evolution rate in nutrient rich medium under shaking conditions. This study aims at assessing the impact of nitrates and sulfates compared with physiological solution on the temporal evolution of Klebsiella oxytoca and Staphylococcus aureus abundance under shaking condition, in aquatic microcosm environment. The two species are potentially human pathogen bacteria when using contaminated water. $K$. oxytoca is mostly isolated in urinary tract and $S$. aureus is mostly isolated in purulent wound on human skin (LE MINOR and VERON, 1989; WHO, 2003). 


\section{MATERIALS AND METHODS}

\subsection{Bacterial characteristics and storage}

Staphylococcus aureus and Klebsiella oxytoca were isolated from stream, on Baird-Parker agar (Bio-Rad) and Hektoen agar medium (Biokard) respectively, using the membrane filtration method (MARCHAL et al., 1991; RODIER, 1996). Their biochemical identification was performed according to HOLT et al. (2000).

For the preparation of bacterial stocks, a colony forming unit (CFU) of each strain from standard agar medium was inoculated into $100 \mathrm{~mL}$ of nutrient broth (Oxford) for $24 \mathrm{~h}$ at $37^{\circ} \mathrm{C}$. After, cells were harvested by centrifugation at $8,000 \mathrm{rev}^{\bullet} \mathrm{min}^{-1}$ for $10 \mathrm{~min}$ at $10^{\circ} \mathrm{C}$ and washed twice with $\mathrm{NaCl}\left(8.5 \mathrm{~g} \bullet \mathrm{L}^{-1}\right)$ solution. Each pellet was re-suspended in $50 \mathrm{~mL}$ of $\mathrm{NaCl}$ solution and $500 \mu \mathrm{L}$ was transferred in sterile tubes to be stocked. The stocks were then stored frozen.

\subsection{Preparation of nitrate and sulfate solutions}

Nitrate and sulfate solutions of concentration $5 \mathrm{~g} \bullet \mathrm{L}^{-1}$ each were prepared. From each of them, three diluted solutions $0.005,0.05$ and $0.5 \mathrm{~g} \bullet \mathrm{L}^{-1}$ respectively, were then prepared. At the same time, the $\mathrm{NaCl}$ solution $\left(8.5 \mathrm{~g} \bullet \mathrm{L}^{-1}\right)$ was prepared. Then $1 \mathrm{~mL}$ of a trypsic peptone solution was added in each of the solutions above, at the final concentration of $10 \mathrm{mg} \bullet \mathrm{L}^{-1}$ of trypsic peptone. This concentration value aimed to mimic the biodegradable oxygen demand $\left(\mathrm{BOD}_{5}\right)$ sometimes registered in surface water (DJUIKOM et al., 2006, 2008). The $\mathrm{pH}$ was then adjusted to 7.0 using $\mathrm{HCl}(1 \mathrm{M})$ and $\mathrm{NaOH}(1 \mathrm{M})$. Series of $199 \mathrm{~mL}$ of each these final solutions $\left(5,0.5,0.05,0.005 \mathrm{~g} \bullet \mathrm{L}^{-1}\right.$ and $\left.\mathrm{NaCl} 8.5 \mathrm{~g} \bullet \mathrm{L}^{-1}\right)$ were transferred in non-chicanery glass flasks (Erlenmeyers $300 \mathrm{~mL}$ ), and then sterilized.

\subsection{Bacterial harvested and inoculation}

Prior to the experiments, each of the stocks frozen vial containing $S$. aureus or $K$. oxytoca, was thawed at room temperature. Then $100 \mu \mathrm{L}$ of the culture was transferred into $10 \mathrm{~mL}$ of nutrient broth (Oxford) in tube and incubated at $37^{\circ} \mathrm{C}$. After $24 \mathrm{~h}, 100 \mu \mathrm{L}$ of the suspension was added to $100 \mathrm{~mL}$ of the same nutrient broth and incubated also for $24 \mathrm{~h}$ at $37^{\circ} \mathrm{C}$. Cells were then harvested by centrifugation at $8,000 \mathrm{rev} \cdot \mathrm{min}^{-1}$ for $10 \mathrm{~min}$ at $10^{\circ} \mathrm{C}$ and washed twice with sterile $\mathrm{NaCl}$ solution $\left(8.5 \mathrm{~g} \bullet \mathrm{L}^{-1}\right)$. The pellets were then resuspended in $50 \mathrm{~mL}$ of sterilized solution containing either
$\mathrm{K}_{2} \mathrm{SO}_{4}$ or $\mathrm{KNO}_{3}$. After serial dilutions, $1 \mathrm{~mL}$ of the suspension was added to $199 \mathrm{~mL}$ of each sterilized salt solution containing peptone as indicated above. Based on our preliminary study, cell concentration was adjusted at $10^{3} \mathrm{CFU} \bullet \mathrm{mL}^{-1}$. Experiments were done in two steps. In the first, only one bacteria strain was added in each solution in the flask and this was called the "pure solution". In the second, the two strains were added at the same time and this was called the "mixed solution". Flasks were then incubated.

\subsection{Incubation of solutions and bacterial analysis}

Incubations of solutions were done on an agitator GLF 3018, for $6 \mathrm{~h}$ at a room temperature $\left(24 \pm 1^{\circ} \mathrm{C}\right)$. For all the experiments, three shaking speeds were used: 300,350 and $400 \mathrm{rev} \cdot \mathrm{min}^{-1}$. The three shaking speeds were chosen based on our preliminary results which showed that at shaking speeds higher than $400 \mathrm{rev} \bullet \mathrm{min}^{-1}$, cells can be destroyed. At shaking speeds lower than $300 \mathrm{rev}^{\bullet} \mathrm{min}^{-1}$, the evolution of cell abundances was similar in most cases. Experiments were carried out under shaking conditions aiming to favor the biodegradation of organic compounds. For each concentration and each shaking speed, solutions were made in triplicate. Analyses to determine concentrations of cultivable bacteria in each solution were performed hourly. Six interval periods were thus chosen. Each analysis was performed from $1 \mathrm{~mL}$ sampled in each solution in the flask, and was done using plate count method on standard agar medium. Petri disks were then incubated at $37^{\circ} \mathrm{C}$ for $24 \mathrm{~h}$ and the CFUs were enumerated.

\subsection{Data analysis}

The hourly mean values of CFU were calculated. Curves of cell abundance evolution have been plotted. Those from the $\mathrm{NaCl}$ were inserted in all curves for a better visualization of the differences in bacterial evolution abundances. Because most of the curves are superposed, the standard deviations were not mentioned on the graphs. An overall comparison (ANOVA) of changes in bacterial abundance has been carried out considering the concentrations and the shaking speeds. The straight Ln (number of CFUs) lines against storage duration were plotted. Each straight line equation $y=a x+b$ has been calculated. The slope a of each regression line was considered as the apparent evolution rate of the abundance of each bacteria species at the third and sixth hour of incubation in each condition. This slope was then considered as the cell apparent growth rate (CAGR) when it was positive, or as the cell apparent inhibition rate (CAIR) when it was negative. 


\section{RESULTS}

\subsection{Evolution of S. aureus abundance in pure solution}

When the shaking speed was $300 \mathrm{rev}^{\bullet} \mathrm{min}^{-1}$, the abundance of $S$. aureus in $\mathrm{NaCl}$ solutions $\left(8.5 \mathrm{~g} \bullet \mathrm{L}^{-1}\right)$ increased gradually from $10 \bullet 10^{2}$ to $43.1 \cdot 10^{2} \mathrm{CFU} \cdot \mathrm{mL}^{-1}$. The highest abundance was recorded after $6 \mathrm{~h}$ of incubation (Figure 1). In solutions containing $\mathrm{K}_{2} \mathrm{SO}_{4}$ at concentrations 0.05 and $0.005 \mathrm{~g} \bullet \mathrm{L}^{-1}$, the highest abundances were recorded respectively after 2 and $5 \mathrm{~h}$ of incubation. At the concentrations 0.5 and $5 \mathrm{~g} \bullet \mathrm{L}^{-1}$, they were recorded after $3 \mathrm{~h}$ of incubation (Figure 1). In solutions containing $\mathrm{KNO}_{3}$, the highest cell abundances were $31.9 \bullet 10^{2}$, $33 \cdot 10^{2}, 37 \cdot 10^{2}$ and $25.4 \cdot 10^{2} \mathrm{CFU} \cdot \mathrm{mL}^{-1}$ at concentrations $0.005,0.05,0.5$ and $5 \mathrm{~g} \bullet \mathrm{L}^{-1}$ respectively (Figure 1 ).

When the solutions were shaked at $350 \mathrm{rev} \bullet \mathrm{min}^{-1}$, the highest cell abundance in $\mathrm{NaCl}$ was $67.5 \cdot 10^{2} \mathrm{CFU} \cdot \mathrm{mL}^{-1}$ and was recorded after $5 \mathrm{~h}$ of incubation (Figure 1). In solutions containing $\mathrm{K}_{2} \mathrm{SO}_{4}$, the cell highest abundances were $77 \bullet 10^{2}$, $67.5 \cdot 10^{2}, 39 \cdot 10^{2}$ and $31 \cdot 10^{2} \mathrm{CFU} \cdot \mathrm{mL}^{-1}$ at concentrations $0.005,0.05,0.5$ and $5 \mathrm{~g} \bullet \mathrm{L}^{-1}$ respectively (Figure 1 ). In solutions containing $\mathrm{KNO}_{3}$, the highest cell abundances were $28.9 \cdot 10^{2}, 30.5 \cdot 10^{2}, 33.9 \cdot 10^{2}$ and $34.3 \cdot 10^{2} \mathrm{CFU} \bullet \mathrm{mL}^{-1}$ respectively recorded at concentrations $0.005,0.05,0.5$ and $5 \mathrm{~g} \bullet \mathrm{L}^{-1}$ (Figure 1 )

At a shaking speed of $400 \mathrm{rev} \bullet \mathrm{min}^{-1}$, the highest cell abundance $\left(87.2 \cdot 10^{2} \mathrm{CFU} \cdot \mathrm{mL}^{-1}\right)$ was recorded after $5 \mathrm{~h}$ of incubation in the $\mathrm{NaCl}$ solution. When the solutions contained $\mathrm{K}_{2} \mathrm{SO}_{4}$ at concentrations 0.005 and $0.05 \mathrm{~g} \bullet \mathrm{L}^{-1}$, it was $68 \cdot 10^{2}$ and $104 \bullet 10^{2} \mathrm{CFU} \bullet \mathrm{mL}^{-1}$ respectively. Both values were recorded after $6 \mathrm{~h}$ of incubation (Figure 1). In solutions containing $\mathrm{KNO}_{3}$ at the concentrations $0.005,0.05,0.5$ and $5 \mathrm{~g} \bullet \mathrm{L}^{-1}$, they were recorded respectively after $5,6,3$ and $2 \mathrm{~h}$ of incubation, and were $30.6 \cdot 10^{2}, 28.7 \cdot 10^{2}, 26.8 \cdot 10^{2}$ and $14.4 \cdot 10^{2} \mathrm{CFU} \cdot \mathrm{mL}^{-1}$ respectively (Figure 1 ).

3.2 Evolution of $\mathrm{K}$. oxytoca abundance in pure solution

At a shaking speed $300 \mathrm{rev} \cdot \mathrm{min}^{-1}$, the increase in cell abundances in solutions containing $\mathrm{NaCl}$ and $\mathrm{K}_{2} \mathrm{SO}_{4}$ was gradual during the second half of the incubation period. The highest cell abundances were recorded after $6 \mathrm{~h}$ of incubation (Figure 2). In solutions containing $\mathrm{KNO}_{3}$, the shape of the cell abundance variations was similar to those observed in $\mathrm{K}_{2} \mathrm{SO}_{4}$ solutions and the highest cell abundances were also recorded after $6 \mathrm{~h}$ of incubation (Figure 2).

The increase in cell abundances was gradual in the second half of the incubation period at a shaking speed $350 \mathrm{rev} \bullet \mathrm{min}^{-1}$, with the exception of the $\mathrm{NaCl}$ solution in which the shape of cell abundance variations was hyperbolic. The highest cell concentrations were $86 \cdot 10^{2} \mathrm{CFU} \cdot \mathrm{mL}^{-1}$ in $\mathrm{NaCl}$ solutions, and $44.1 \cdot 10^{2}, 70.4 \bullet 10^{2}, 29.5 \cdot 10^{2}$ and $26 \bullet 10^{2} \mathrm{CFU} \cdot \mathrm{mL}^{-1}$ in those containing $\mathrm{K}_{2} \mathrm{SO}_{4}$ at concentrations $0.005,0.05$, 0.5 and $5 \mathrm{~g} \bullet \mathrm{L}^{-1}$ respectively (Figure 2). In solutions containing $\mathrm{KNO}_{3}$, the curves of cell abundance variations were hyperbolic at $0.005 \mathrm{~g} \bullet \mathrm{L}^{-1}$, and sinusoidal in the others. At concentrations 0.5 and $5 \mathrm{~g}^{-\mathrm{L}^{-1}}$ of $\mathrm{KNO}_{3}$, they were $19.2 \bullet 10^{2}$ and $32 \bullet 10^{2}$ $\mathrm{CFU} \cdot \mathrm{mL}^{-1}$ respectively, and were recorded after 4 and $3 \mathrm{~h}$ of incubation (Figure 2).

The evolution of the cell abundance was gradual in solutions containing $\mathrm{K}_{2} \mathrm{SO}_{4}$ at concentrations $0.005,0.5$ and $5 \mathrm{~g} \bullet \mathrm{L}^{-1}$ when the medium was shaked at $400 \mathrm{rev} \bullet \mathrm{min}^{-1}$, and the shape of the curve of cell abundance variations seems sinusoidal at $0.05 \mathrm{~g} \bullet \mathrm{L}^{-1}$ (Figure 2). In solutions containing $\mathrm{KNO}_{3}$, all curves of cell abundance variations were sinusoidal. At the concentrations $0.005,0.05,0.5$ and $5 \mathrm{~g} \bullet \mathrm{L}^{-1}$, the highest cell abundances were $30 \bullet 10^{2}, 27.7 \cdot 10^{2}, 24.6 \cdot 10^{2}$ and $21.4 \bullet 10^{2}$ $\mathrm{CFU} \bullet \mathrm{mL}^{-1}$ respectively (Figure 2 ).

\subsection{Evolution of $S$. aureus and $\mathrm{K}$. oxytoca in mixed solutions}

When both cell species were present simultaneously, the curves of their abundance variation were hyperbolic in $\mathrm{NaCl}$ solution at a shaking speed of $300 \mathrm{rev} \cdot \mathrm{min}^{-1}$ and $400 \mathrm{rev} \bullet \mathrm{min}^{-1}$ for $K$. oxytoca, and at $350 \mathrm{rev} \bullet \mathrm{min}^{-1}$ and $400 \mathrm{rev} \bullet \mathrm{min}^{-1}$ for $S$. aureus (Figures 3 and 4). At $300 \mathrm{rev}^{\bullet} \mathrm{min}^{-1}$, the highest cell abundance was $48.2 \cdot 10^{2} \mathrm{CFU} \bullet \mathrm{mL}^{-1}$ for $K$. oxytoca; this value was noted just after $3 \mathrm{~h}$ of incubation. That of $S$. aureus was $32.1 \cdot 10^{2} \mathrm{CFU} \cdot \mathrm{mL}^{-1}$ and was recorded after $6 \mathrm{~h}$ of incubation (Figures 3 and 4). When the solutions contained $\mathrm{K}_{2} \mathrm{SO}_{4}$, curves of cell abundance variations were sinusoidal, those of $S$. aureus except at concentrations 0.005 and $0.05 \mathrm{~g}^{\bullet} \mathrm{L}^{-1}$ (Figure 3).

At a shaking speed $350 \mathrm{rev} \bullet \mathrm{min}^{-1}$, the highest abundance of each species was recorded at the end of fourth hour of incubation in a $\mathrm{NaCl}$ solution. It was $21.4 \cdot 10^{2} \mathrm{CFU} \cdot \mathrm{mL}^{-1}$ for K. oxytoca, and $43.7 \cdot 10^{2} \mathrm{CFU} \bullet \mathrm{mL}^{-1}$ for $S$. aureus (Figures 4). In solutions containing $\mathrm{K}_{2} \mathrm{SO}_{4}$, the abundances reached $28.6 \bullet 10^{2} \mathrm{CFU} \cdot \mathrm{mL}^{-1}$ for $K$. oxytoca, and $30 \bullet 10^{2} \mathrm{CFU} \bullet \mathrm{mL}^{-1}$ for $S$. aureus at concentration $0.005 \mathrm{~g} \bullet \mathrm{L}^{-1}, 20 \bullet 10^{2} \mathrm{CFU} \bullet \mathrm{mL}^{-1}$ for $K$. oxytoca and $19.5 \cdot 10^{2} \mathrm{CFU} \cdot \mathrm{mL}^{-1}$ for $S$. aureus at concentration $0.05 \mathrm{~g} \bullet \mathrm{L}^{-1}, 18.6 \bullet 10^{2} \mathrm{CFU} \bullet \mathrm{mL}^{-1}$ for $K$. oxytoca and $21.7 \cdot 10^{2} \mathrm{CFU} \bullet \mathrm{mL}^{-1}$ for $S$. aureus at $0.5 \mathrm{~g} \bullet \mathrm{L}^{-1}$, and $14.3 \cdot 10^{2} \mathrm{CFU} \cdot \mathrm{mL}^{-1}$ for $K$. oxytoca and $22 \cdot 10^{2} \mathrm{CFU} \cdot \mathrm{mL}^{-1}$ for $S$. aureus at $5 \mathrm{~g} \bullet \mathrm{L}^{-1}$. At this shaking speed, all highest cell 

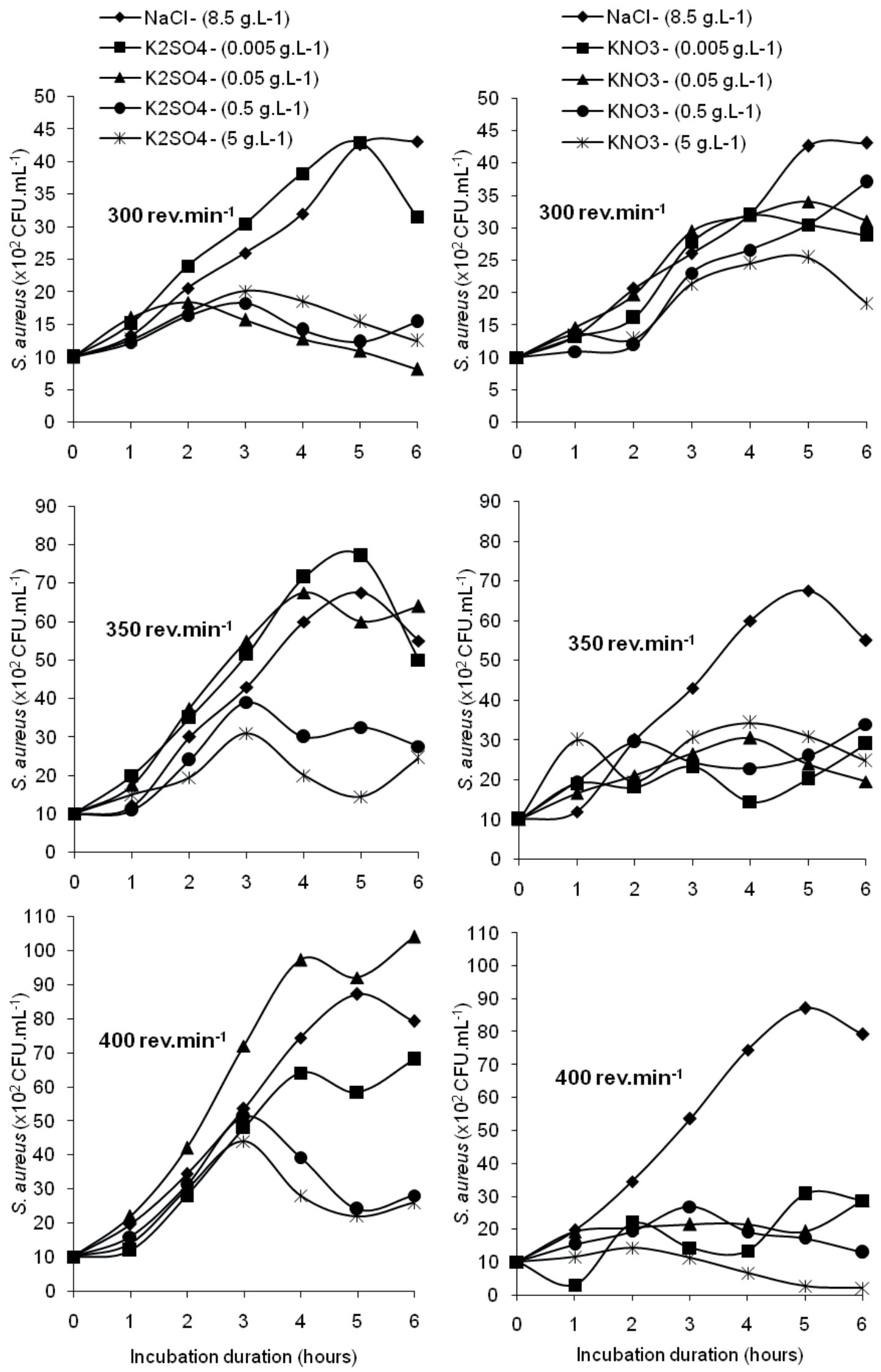

Figure 1. Temporal variation of mean values of the $S$. aureus abundance in each of $\mathrm{K}_{2} \mathrm{SO}_{4}$ and $\mathrm{KNO}_{3}$ solutions,

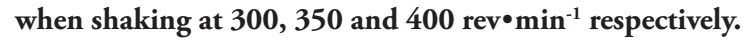

Variation temporelle des valeurs moyennes des abondances de $\mathrm{S}$. aureus dans les solutions de $\mathrm{K}_{2} \mathrm{SO}_{4}$ et $\mathrm{KNO}_{3}$ aux vitesses d'agitation 300, 350 et 400 rev $^{\bullet} \mathrm{min}^{-1}$, respectivement. 

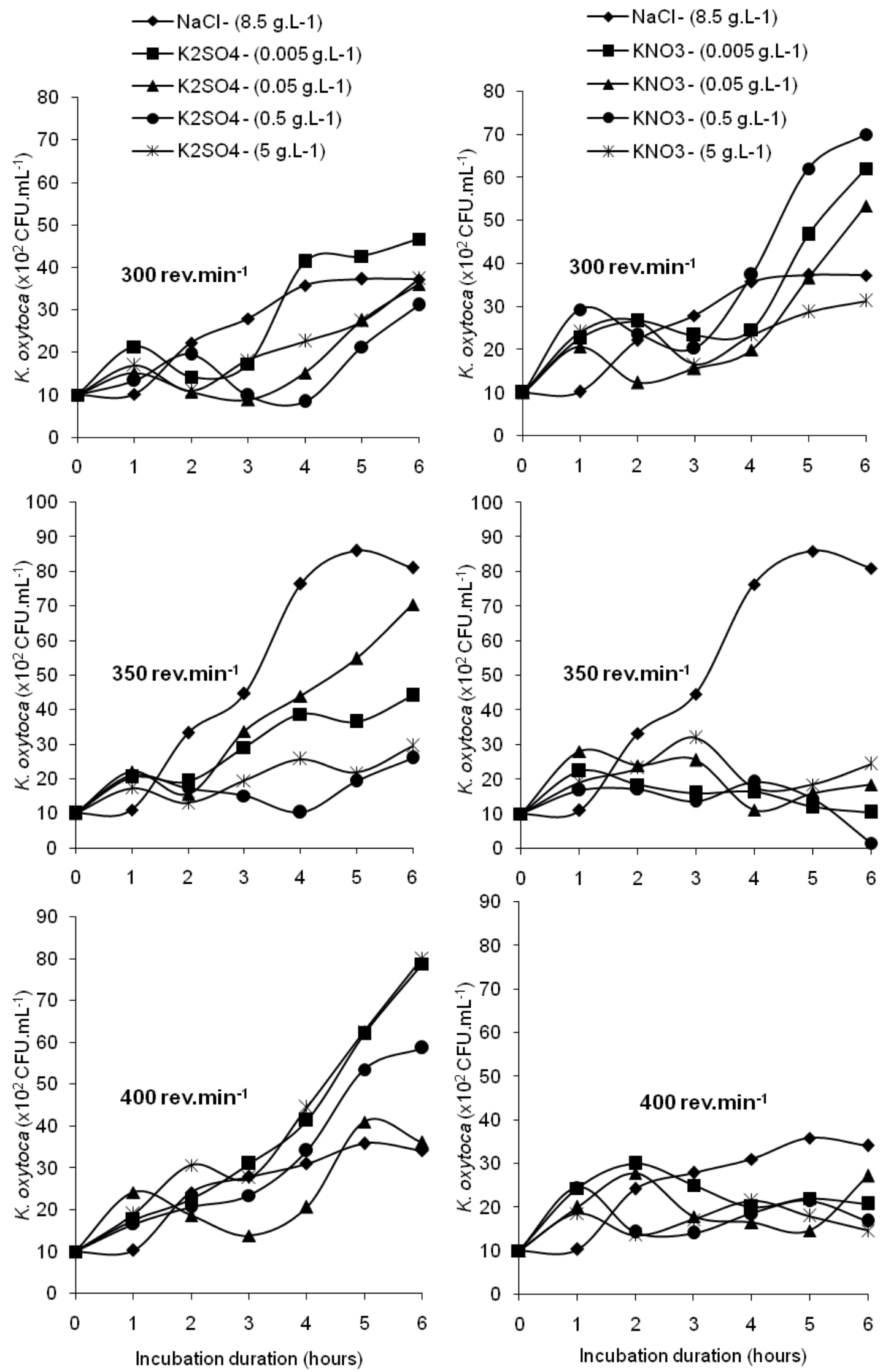

Figure 2. Temporal variation of mean values of the $K$. oxytoca abundance in each of $\mathrm{K}_{2} \mathrm{SO}_{4}$ and $\mathrm{KNO}_{3}$ solutions, when shaking at 300,350 and $400 \mathrm{rev} \cdot \mathrm{min}^{-1}$ respectively.

Variation temporelle des valeurs moyennes des abondances de $\mathrm{K}$. oxytoca dans les solutions de $\mathrm{K}_{2} \mathrm{SO}_{4}$ et $\mathrm{KNO}_{3}$ aux vitesses d'agitation 300, 350 et 400 rev ${ }^{\circ i n^{-1}}$, respectivement. 


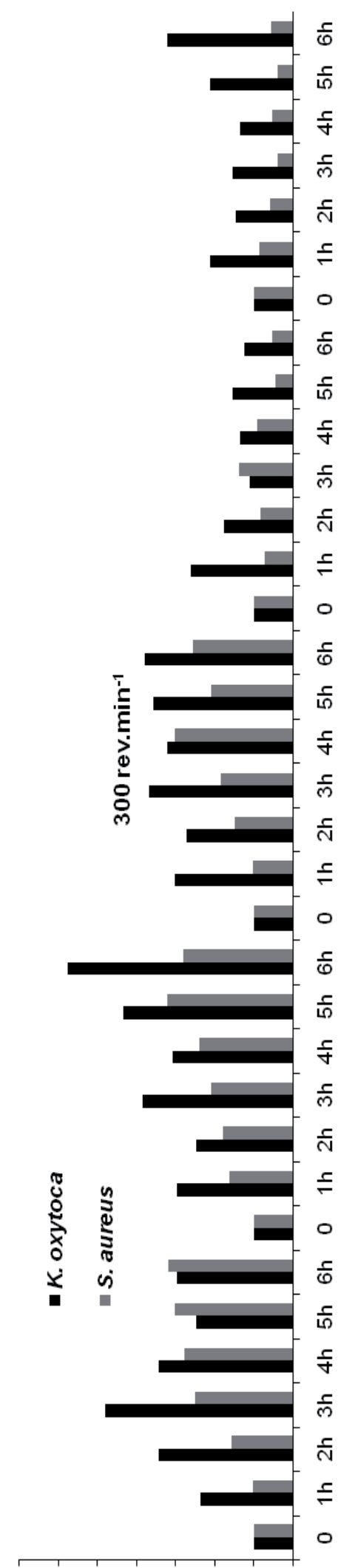

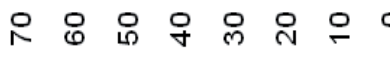
$\left(1.7 \mathrm{M} \cap \cap \exists \partial_{z} 01 \mathrm{l}\right)$

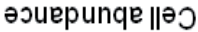

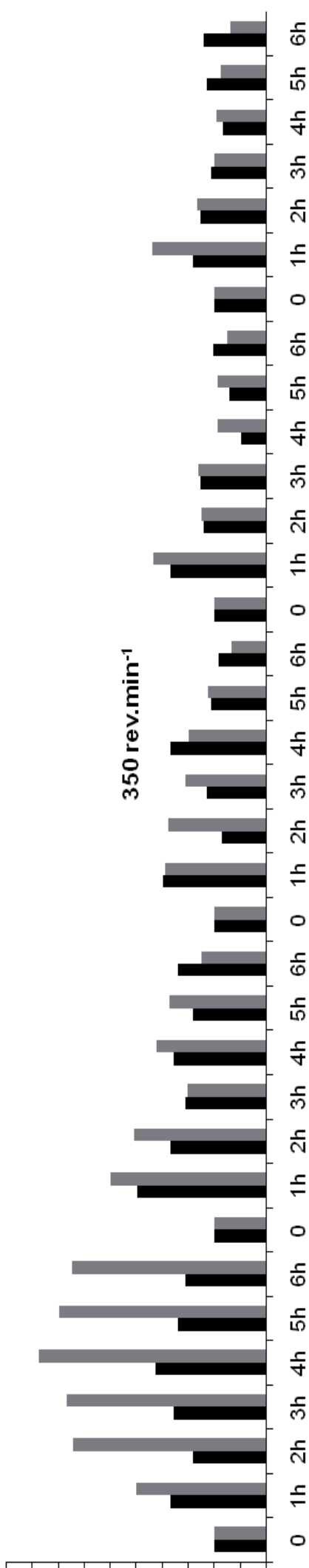

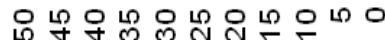

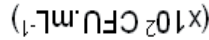
әэuepunqe $\| ә \supset$
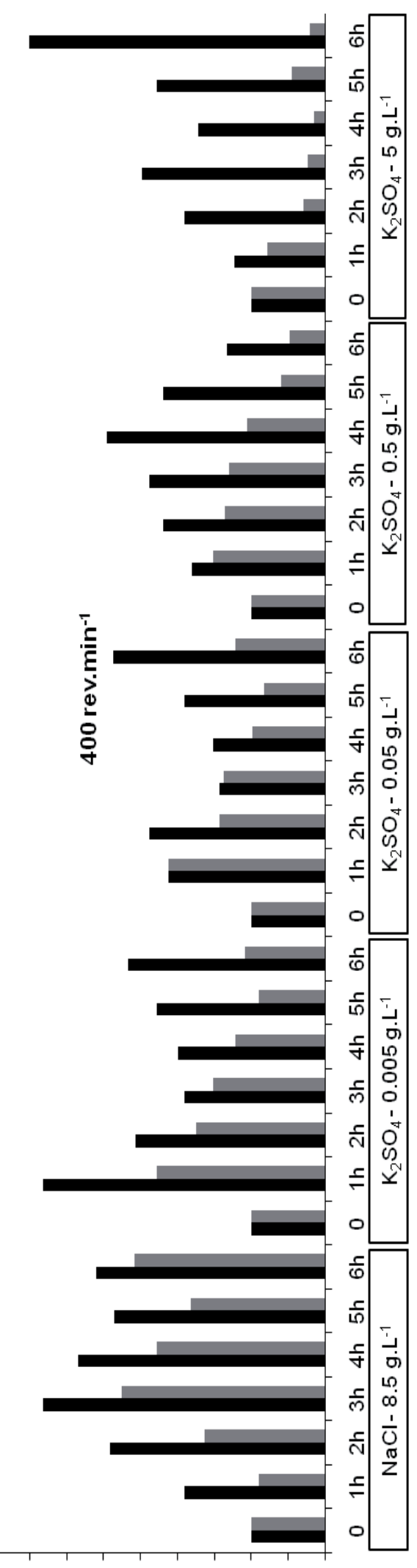

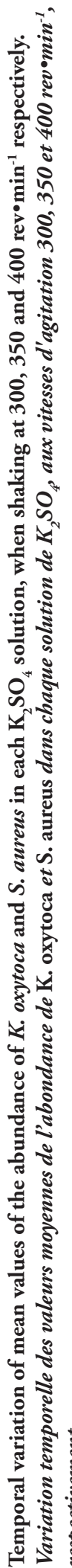



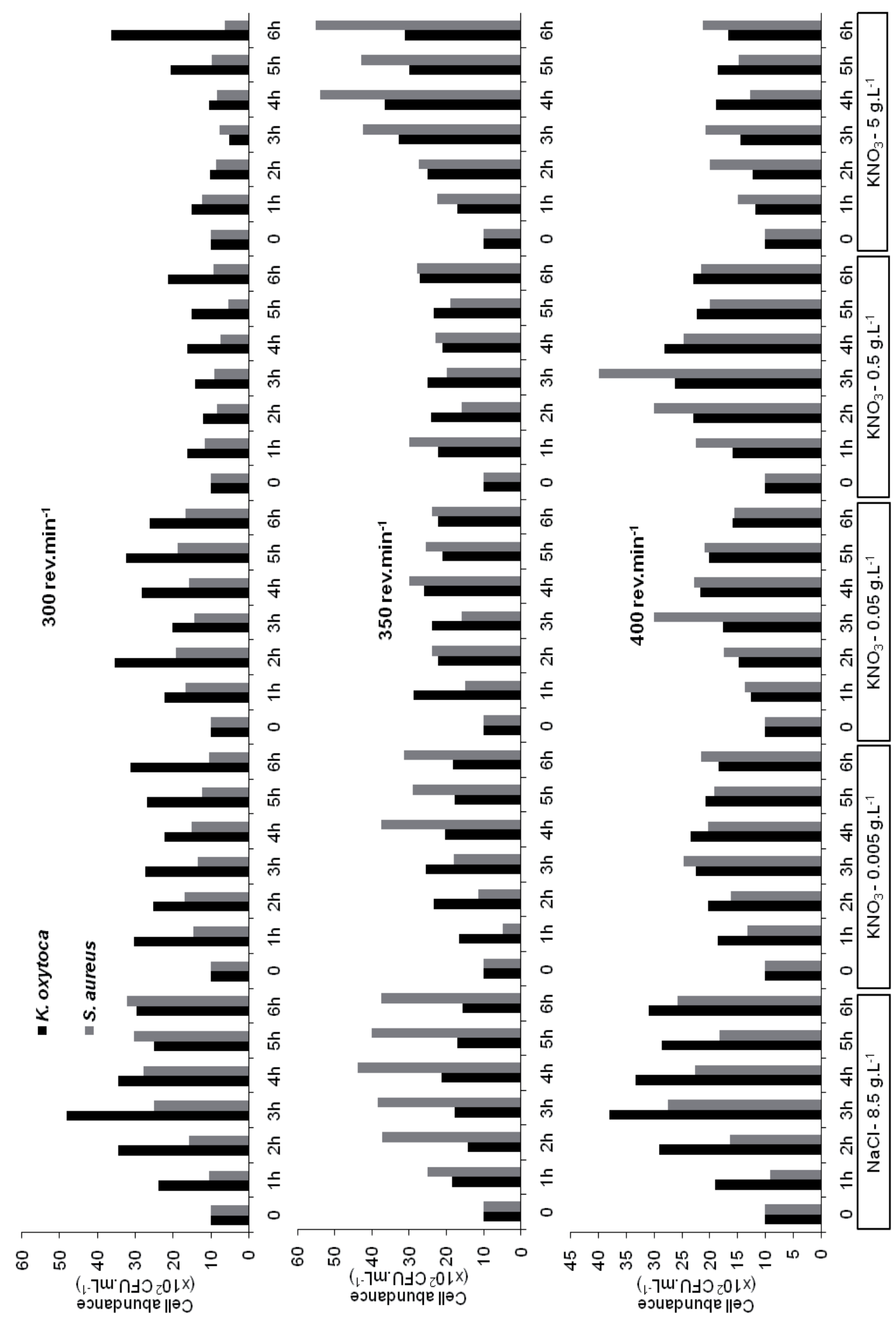

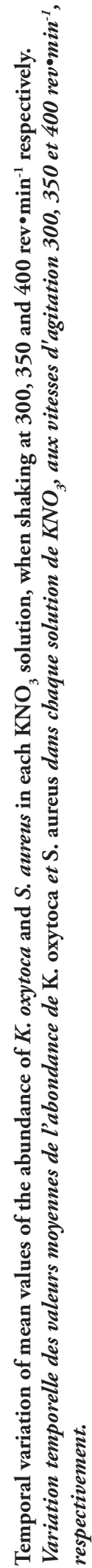


abundances were recorded just after 1 or $2 \mathrm{~h}$ of incubation (Figure 3).

At $400 \mathrm{rev} \cdot \mathrm{min}^{-1}$, the highest cell abundances of both bacterial species were noted at the end of the first $3 \mathrm{~h}$ of incubation in $\mathrm{NaCl}$ solutions. They were $38.1 \cdot 10^{2} \mathrm{CFU} \bullet \mathrm{mL}^{-1}$ for $K$. oxytoca and $27.6 \bullet 10^{2} \mathrm{CFU} \bullet \mathrm{mL}^{-1}$ for $S$. aureus (Figures 3 and 4). In the presence of $\mathrm{K}_{2} \mathrm{SO}_{4}$ at concentrations 0.005 , $0.05,0.5$ and $5 \mathrm{~g} \bullet \mathrm{L}^{-1}$, the highest abundances of $K$. oxytoca were $38.1 \cdot 10^{2}, 28.7 \cdot 10^{2}, 29.5 \cdot 10^{2}$ and $40 \bullet 10^{2} \mathrm{CFU} \bullet \mathrm{mL}^{-1}$ respectively. Those of $S$. aureus were $22.7 \cdot 10^{2}, 21.2 \cdot 10^{2}$, $15.2 \cdot 10^{2}$ and $10 \bullet 10^{2} \mathrm{CFU} \bullet \mathrm{mL}^{-1}$ respectively, and were recorded just after $1 \mathrm{~h}$ of incubation, except in the solution at $5 \mathrm{~g} \cdot \mathrm{L}^{-1}$ in which cell abundance declined during the incubation period (Figure 3).

When both cell species were present simultaneously in solutions containing $\mathrm{KNO}_{3}$, the increase in $S$. aureus abundances was noted after $1 \mathrm{~h}$ of incubation in most cases at $300 \mathrm{rev} \bullet \mathrm{min}^{-1}$ (Figure 4). At a shaking speed of $350 \mathrm{rev} \bullet \mathrm{min}^{-1}$, the highest abundances of $S$. aureus were $37.5 \cdot 10^{2}, 25.5 \cdot 10^{2}$, $30 \bullet 10^{2}$ and $55 \cdot 10^{2} \mathrm{CFU} \cdot \mathrm{mL}^{-1}$ at concentrations 0.005 , $0.05,0.5$ and $5 \mathrm{~g}^{\bullet} \mathrm{L}^{-1}$ respectively; those of $K$. oxytoca at the same concentrations were $25.5 \cdot 10^{2}, 28.9 \bullet 10^{2}, 27.2 \cdot 10^{2}$ and $56.7 \cdot 10^{2} \mathrm{CFU} \cdot \mathrm{mL}^{-1}$ (Figure 4 ). When the medium was agitated at $400 \mathrm{rev} \bullet \mathrm{min}^{-1}$, the cell abundance variation also varied with the concentration of $\mathrm{KNO}_{3}$, and the curves seem hyperbolic in most cases (Figure 4).

\subsection{Comparison of the evolution of bacterial abundances}

An overall comparison (ANOVA) of changes in bacterial abundances has been carried out considering the concentrations of salts used, for each shaking speed. It appeared that at all shaking speeds of the medium in mixed culture containing $\mathrm{K}_{2} \mathrm{SO}_{4}$, changes in abundances of $S$. aureus differed significantly $(\mathrm{P}<0.001)$ from one concentration to another. Meanwhile, changes in abundances of $K$. oxytoca differed significantly $(\mathrm{P}<0.05)$ from one concentration to another only at the shaking speeds of 300 and $350 \mathrm{rev} \bullet \mathrm{min}^{-1}$ (Table 1). In mixed culture containing $\mathrm{KNO}_{3}$ and in pure culture containing each of the two salts used, the magnitude of the differences among changes in bacteria abundances varied with the salt concentration (Table 1). An overall comparison of the evolution of cell abundances has also been carried out considering the shaking speeds of the medium. It has been noted that in mixed and pure cultures, changes in abundances of $S$. aureus differed significantly $(\mathrm{P}<0.001)$ with a shaking speed when the medium contained $\mathrm{KNO}_{3}$ at a concentration of $5 \mathrm{~g} \cdot \mathrm{L}^{-1}$ (Table 2). In other cases, the magnitudes of the differences are very variable.

\subsection{Assessment of bacterial abundance apparent evolution rates}

The slope a of each regression line was calculated as the apparent evolution rate of each bacteria species abundance at the third or sixth hour of incubation in each condition. This slope was then considered as the cell apparent growth rate (CAGR) when it was positive, or to the cell apparent inhibition rate (CAIR) when it was negative. It appeared that in $\mathrm{NaCl}$ solutions, the CAGRs of $S$. aureus in pure culture varied during the first $3 \mathrm{~h}$ of incubation, from $0.331 \cdot \mathrm{h}^{-1}$ when the solutions were agitated at $300 \mathrm{rev} \bullet \mathrm{min}^{-1}$, to $0.559 \bullet \mathrm{h}^{-1}$ when they were agitated at $400 \mathrm{rev}^{\bullet} \mathrm{min}^{-1}$. Considering the full period of incubation $(6 \mathrm{~h})$, it was noted that the CAGRs in these solutions varied from $0.255 \cdot \mathrm{h}^{-1}$ to $0.355 \cdot \mathrm{h}^{-1}$ (Table 3). There was a decrease in the cell growth rate during the second half of the incubation period. In mixed culture, CAGRs varied from $0.317 \cdot \mathrm{h}^{-1}$ to $0.444 \cdot \mathrm{h}^{-1}$ during the first $3 \mathrm{~h}$ of incubation, and the greatest value was recorded when the solution was agitated at $350 \mathrm{rev} \bullet \mathrm{min}^{-1}$. However, when considering the full period of incubation, the CAGRs during this period varied from $0.162 \cdot \mathrm{h}^{-1}$ to $0.221 \cdot \mathrm{h}^{-1}$, the highest value was also observed when the solution was agitated at $350 \mathrm{rev} \bullet \mathrm{min}^{-1}$ (Table 3). This shaking speed seems to create the most favorable conditions to the $S$. aureus multiplication in the presence of $K$. oxytoca in $\mathrm{NaCl}$ solutions containing biodegradable organic matter.

In the presence of $\mathrm{K}_{2} \mathrm{SO}_{4}$ or $\mathrm{KNO}_{3}$, there was a relative variability of $S$. aureus apparent evolution rates in pure cultures as well as in mixed cultures. For the whole, when considering the pure cultures, the highest CAGR of $S$. aureus during the first $3 \mathrm{~h}$ of incubation was $0.656 \cdot \mathrm{h}^{-1}$ in the presence of $\mathrm{K}_{2} \mathrm{SO}_{4}$ $\left(0.05 \mathrm{~g} \bullet \mathrm{L}^{-1}, 400 \mathrm{rev} \bullet \mathrm{min}^{-1}\right)$, and $0.353 \bullet \mathrm{h}^{-1}$ in the presence of $\mathrm{KNO}_{3}\left(0.05 \mathrm{~g} \bullet \mathrm{L}^{-1}, 300 \mathrm{rev} \bullet \mathrm{min}^{-1}\right)$ (Table 3). The CAGRs were lower after $6 \mathrm{~h}$ of incubation (Table 3 ). This would be due to the decrease in cell growth rates during the second half of the incubation period. When considering the mixed culture, the highest CAGR value during the first $3 \mathrm{~h}$ of incubation was $0.235 \cdot \mathrm{h}^{-1}$ in the presence of $\mathrm{K}_{2} \mathrm{SO}_{4}\left(0.005 \mathrm{~g} \bullet \mathrm{L}^{-1}\right.$, $\left.300 \mathrm{rev} \bullet \mathrm{min}^{-1}\right)$, and $0.454 \cdot \mathrm{h}^{-1}$ in the presence of $\mathrm{KNO}_{3}$ $\left(5 \mathrm{~g} \bullet \mathrm{L}^{-1}, 350 \mathrm{rev} \bullet \mathrm{min}^{-1}\right)$. As in pure cultures, the CAGRs were also lower after $6 \mathrm{~h}$ of incubation (Table 3). Considering the full period of incubation in mixed cultures, it was noted that the cell apparent evolution rates were negative in the presence of $\mathrm{K}_{2} \mathrm{SO}_{4}$ at all concentrations, when the solutions were shaked at 350 and $400 \mathrm{rev}^{\bullet} \mathrm{min}^{-1}$, and led to the CAIRs (Table 3). This would be due to a greater inhibition of $S$. aureus growth during the second half of the incubation period. The highest value of CAIR in the presence of $\mathrm{K}_{2} \mathrm{SO}_{4}$ considering the first $3 \mathrm{~h}$ of the incubation was $0.520 \bullet \mathrm{h}^{-1}\left(5 \mathrm{~g} \bullet \mathrm{L}^{-1}, 400 \mathrm{rev} \bullet \mathrm{min}^{-1}\right)$; in the presence of $\mathrm{KNO}_{3}$, it was $0.115 \bullet \mathrm{h}^{-1}\left(5 \mathrm{~g} \bullet \mathrm{L}^{-1}, 300 \mathrm{rev} \bullet \mathrm{min}^{-1}\right)$. No CAIR was noted during this incubation period in pure cultures (Table 3). 
Table 1. Comparison (ANOVA) among the evolution of the bacterial abundances when considering the salt concentrations, with respect of the shaking speed.

Tableau 1. Comparaison (ANOVA) entre l'évolution des abondances bactériennes en considérant les concentrations des sels, en fonction de la vitesse d'agitation du milieu.

\begin{tabular}{|c|c|c|c|c|c|c|c|}
\hline \multirow{3}{*}{\multicolumn{2}{|c|}{$\begin{array}{l}\text { Salt used and } \\
\text { culture conditions }\end{array}$}} & \multicolumn{6}{|c|}{ Shaking speeds and bacteria species } \\
\hline & & \multicolumn{2}{|c|}{$300 \mathrm{rev} \bullet \mathrm{min}^{-1}$} & \multicolumn{2}{|c|}{$350 \mathrm{rev} \bullet \mathrm{min}^{-1}$} & \multicolumn{2}{|c|}{$400 \mathrm{rev} \bullet \mathrm{min}^{-1}$} \\
\hline & & \multirow{2}{*}{$\frac{K . \text { oxytoca }}{4.150^{* *}}$} & \multirow{2}{*}{$\begin{array}{l}\text { S. aureus } \\
8.775^{* * *}\end{array}$} & \multirow{2}{*}{$\frac{K . \text { oxytoca }}{3.609^{*}}$} & \multirow{2}{*}{$\begin{array}{l}\text { S. aureus } \\
11.036^{* * *}\end{array}$} & \multirow{2}{*}{$\begin{array}{c}K . \text { oxytoca } \\
1.071\end{array}$} & \multirow{2}{*}{$\begin{array}{l}\text { S. aureus } \\
7.636^{* * *}\end{array}$} \\
\hline M. culture & $\mathrm{K}_{2} \mathrm{SO}_{4}$ & & & & & & \\
\hline & $\mathrm{KNO}_{3}$ & $3.729^{*}$ & $9.015^{* *}$ & 2.409 & 3.185 & $4.629^{* *}$ & 1.336 \\
\hline \multirow[t]{2}{*}{ P. culture } & $\mathrm{K}_{2} \mathrm{SO}_{4}$ & 1.359 & $5.099^{* *}$ & 3.324 & 2.654 & 0.983 & 2.628 \\
\hline & $\mathrm{KNO}_{3}$ & 0.842 & 0.760 & $6.126^{* *}$ & 3.088 & 1.855 & $8.481^{* * *}$ \\
\hline
\end{tabular}

$\mathrm{N}=28$ observations; M. culture: mixed culture; P. culture: pure culture;

Significant difference $\left({ }^{*}: \mathrm{P}<0.05 ;{ }^{* *}: \mathrm{P}<0.01 ;{ }^{* *}: \mathrm{P}<0.001\right)$

Table 2. Comparison (ANOVA) among the evolution of the bacterial abundances when considering the shaking speeds, with respect of the salt concentration.

Tableau 2. Comparaison (ANOVA) entre l'évolution des abondances bactériennes en considérant les vitesses d'agitation, en fonction de la concentration en sel du milieu.

\begin{tabular}{|c|c|c|c|c|c|c|c|c|c|}
\hline \multirow{3}{*}{$\begin{array}{l}\text { Salt used } \\
\text { and } \\
\text { culture conditions }\end{array}$} & & \multicolumn{8}{|c|}{ Bacteria species and salt concentrations $\left(g \bullet \mathrm{L}^{-1}\right)$} \\
\hline & & \multicolumn{4}{|c|}{$K$ oxytoca } & \multicolumn{4}{|c|}{ S. aureus } \\
\hline & & 0.005 & 0.05 & 0.5 & 5 & 0.005 & 0.05 & 0.5 & 5 \\
\hline \multirow[t]{2}{*}{ M. culture } & $\mathrm{K}_{2} \mathrm{SO}_{4}$ & $4.668^{*}$ & $10.627^{* *}$ & $4.532^{*}$ & 3.252 & 2.368 & 2.124 & 1.397 & $6.954^{* *}$ \\
\hline & $\mathrm{KNO}_{3}$ & 2.385 & 3.449 & $3.649^{*}$ & $4.080^{*}$ & 1.480 & 1.153 & $10.088^{* *}$ & $13.088^{* * *}$ \\
\hline \multirow[t]{2}{*}{ P. culture } & $\mathrm{K}_{2} \mathrm{SO}_{4}$ & 0.645 & 2.525 & 3.230 & 3.407 & 1.314 & $6.601^{* *}$ & $3.711^{*}$ & 2.657 \\
\hline & $\mathrm{KNO}_{3}$ & $3.614^{*}$ & 0.530 & $5.700^{*}$ & 2.616 & 0.658 & 0.631 & 0.470 & $12.240^{* * *}$ \\
\hline
\end{tabular}

$\mathrm{N}=21$ observations; M. culture: mixed culture; P. culture: pure culture;

Significant difference ${ }^{*}: \mathrm{P}<0.05$; ${ }^{* *}: \mathrm{P}<0.01$; $\left.{ }^{* * *}: \mathrm{P}<0.001\right)$ 


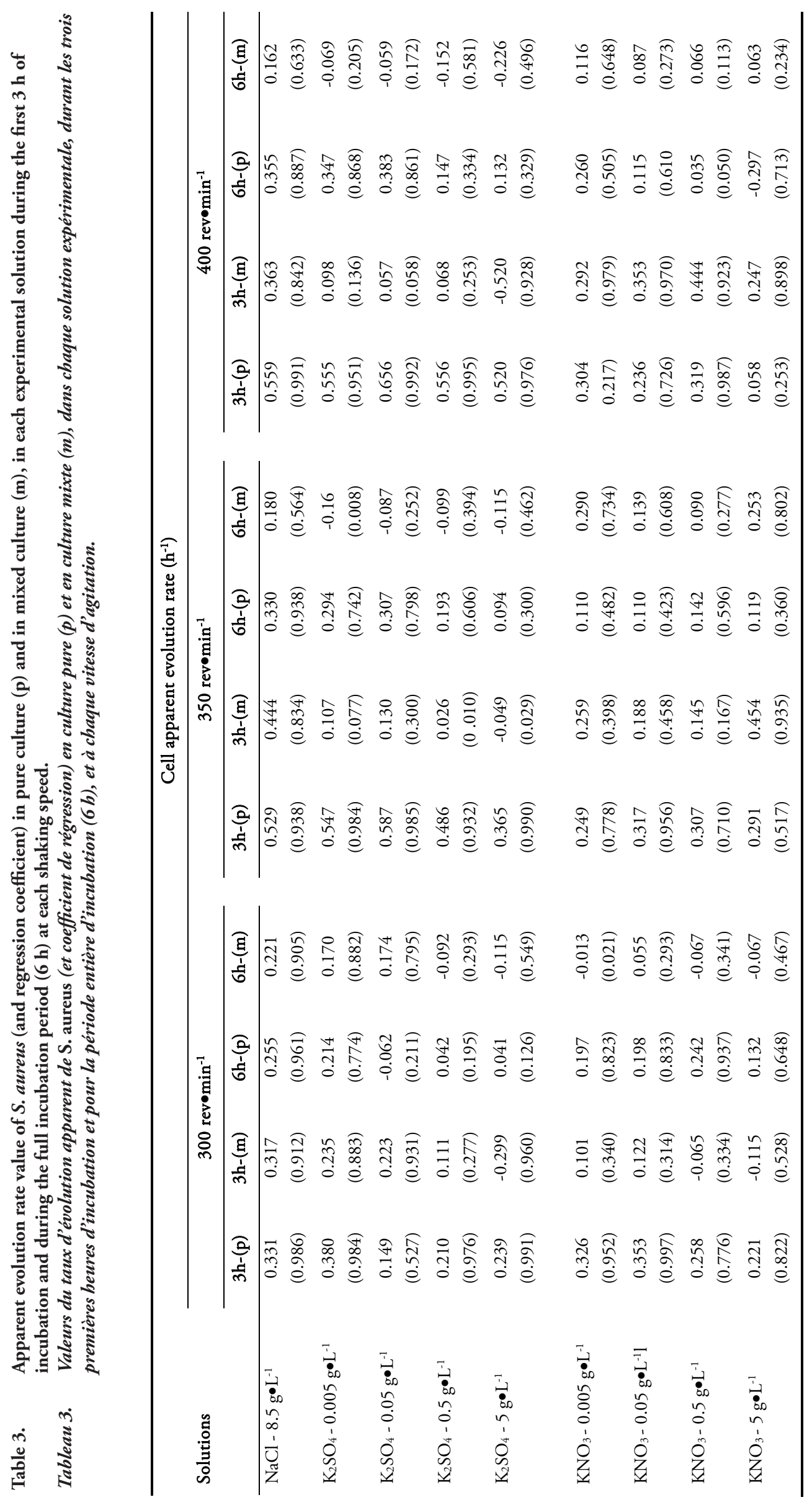


For $K$. oxytoca, the greatest CAGR value in pure cultures in $\mathrm{NaCl}$ solutions after the first $3 \mathrm{~h}$ of incubation, at the shaking speed of $350 \mathrm{rev} \bullet \mathrm{min}^{-1}$ was $0.558 \cdot \mathrm{h}^{-1}$. In the presence of S. aureus, its highest CAGR was $0.509 \cdot \mathrm{h}^{-1}$; it was recorded at the shaking speed of $300 \mathrm{rev}^{\bullet} \mathrm{min}^{-1}$ (Table 4). As observed in the case of $S$. aureus, the apparent evolution rates of $K$. oxytoca in the presence of $\mathrm{K}_{2} \mathrm{SO}_{4}$ or $\mathrm{KNO}_{3}$ underwent a relative variability with respect to the shaking speed and the concentration of salts in solutions. Considering the first $3 \mathrm{~h}$ of the incubation, it was noted that in the presence of $\mathrm{K}_{2} \mathrm{SO}_{4}$ the highest CAGR value of $K$. oxytoca in pure cultures was $0.388 \bullet \mathrm{h}^{-1}\left(0.005 \mathrm{~g} \bullet \mathrm{L}^{-1}, 300 \mathrm{rev} \bullet \mathrm{min}^{-1}\right)$. In mixed cultures, it was $0.363 \bullet \mathrm{h}^{-1}\left(0.005 \mathrm{~g} \bullet \mathrm{L}^{-1}, 400 \mathrm{rev} \bullet \mathrm{min}^{-1}\right)$. In the presence of $\mathrm{KNO}_{3}$, it was $0.367 \cdot \mathrm{h}^{-1}$ in pure cultures and $0.393 \cdot \mathrm{h}^{-1}$ in mixed cultures. Both values were noted at the concentration $5 \mathrm{~g} \bullet \mathrm{L}^{-1}$ and at a shaking speed of $350 \mathrm{rev} \bullet \mathrm{min}^{-1}$ (Table 4). As observed in the case of $S$. aureus, the apparent evolution rates of $K$. oxytoca were relatively low when considering the full period of incubation. Its highest CAIR value during the first $3 \mathrm{~h}$ of incubation in the presence of $\mathrm{K}_{2} \mathrm{SO}_{4}$ was $0.07 \cdot \mathrm{h}^{-1}$ in pure cultures $\left(0.05 \mathrm{~g} \cdot \mathrm{L}^{-1}, 300 \mathrm{rev} \bullet \mathrm{min}^{-1}\right)$, and $0.044 \bullet \mathrm{h}^{-1}$ in mixed cultures $\left(0.05 \mathrm{~g} \bullet \mathrm{L}^{-1}, 350 \mathrm{rev}^{\bullet} \mathrm{min}^{-1}\right)$ (Table 4). In the presence of $\mathrm{KNO}_{3}$, it was $0.239 \bullet \mathrm{h}^{-1}$ in mixed cultures $\left(5 \mathrm{~g}^{\bullet} \mathrm{L}^{-1}\right.$, $\left.300 \mathrm{rev}^{\bullet} \mathrm{min}^{-1}\right)$. No CAIR was noted in the pure cultures during this incubation period (Table 4).

\section{DISCUSSION}

This study shows that at all shaking speeds in $\mathrm{NaCl}$ solution, the abundance of $S$. aureus or $K$. oxytoca increases with the increasing of the incubation duration. In pure cultures, the maximum abundances were recorded after 5 or $6 \mathrm{~h}$ of incubation. In mixed cultures, they were recorded after 3 or $4 \mathrm{~h}$ of incubation. Moreover, their evolution seems hyperbolic in most cases. However, in solutions containing $\mathrm{K}_{2} \mathrm{SO}_{4}$ or $\mathrm{KNO}_{3}$, a temporal variability in evolution rates of cell abundances was noted from one concentration in salt to another for the same shaking speed, and from one shaking speed to another for the same salt concentration. This variability was also noted in pure and mixed cultures. Changes in evolution rates of cell abundance may be related to the accumulation of certain toxic chemicals which temporarily became toxic to the cells, and which would also decrease or inhibit their proliferation. Over time, the complexion of these products with others could neutralize them and allow an increase in cell growth rates. In aqueous solutions, sulfates might be transformed to sulfide with the reaction of biogenic hydrogen sulfide, extracellular substances and organic acid (ZHAO et al., 2007).

Results showed that shaking speeds impacted the cell apparent evolution rates. The role of the turbulence of aquatic medium on the bacterial abundance evolution rate has also been assessed by MOESENEDER and HERNDL (1995). They noted that the bacterial growth rate was significantly modified by the turbulence with respect to the substrate. TALON et al. (1999) noted that in static conditions, the synthesis of nitrate reductase enzyme is maximal during cell exponential growth phases whereas in shaking condition, its synthesis is maximal at the beginning of the stationary phase. Agitation speed is also an important factor in the fermentation process since it will increase the amount of dissolved oxygen in the cultivation medium. DARAH and IBRAHIM (1998) reported that a maximum lignin peroxidase activity and a maximum fungal growth were achieved when the optimal agitation speed of $150 \mathrm{rev} \cdot \mathrm{min}^{-1}$ was used. Some authors, when investigating on the activity of two Bacillus species noted that it was maximal at the outset of incubation under agitation speed of $300 \mathrm{rev} \cdot \mathrm{min}^{-1}$ (EL-TAYEB et al., 2007). This situation reflects an in vivolimited functioning of most enzymes in bacteria. When investigating on the impact of hydrological factors on the microbial distribution in aquatic microcosm, PINHASSI et al. (2004) noted that agitation was a noninvasive means to induce phytoplankton; and changes in phytoplankton community composition were followed by shifts in bacterioplankton community composition. Other investigations showed that mixing during resuspension events may also have profound effects on the dynamics of resuspended benthic microbial food webs (GARSTECKI and WICKHAM, 2001).

Excessive agitation would produce greater mechanical forces or hydrodynamic shear stresses and this condition is known to damage fungal mycelia and pellets (PORCEL et al., 2005), that lead to cell destruction thus lowering the enzyme production. PAPAGIANNI et al. (2001) also found that the enzyme production was strongly affected by the agitation. At higher agitation rates, the enzyme production dropped. Agitation speed of the culture broth has a variety of effects on microorganisms, including rupture of the cell wall, change in the morphology of filamentous microorganisms, variation in the efficiency and rate of growth and also variation in the rate of formation of the desired product (PORCEL et al., 2005). However, it has been reported that a marine bacterium (Vibrio splendidus) was not affected by the turbulence of the medium, whereas a protistan predator (Paraphysomonas sp.) was significantly affected; bacterial grazing mortality by Paraphysomonas sp. was 1.3- to 2.5-fold greater in the turbulent than static treatments among all four temperatures, and the rates of cell-specific ingestion of bacteria by Paraphysomonas $s p$. was 2 -fold greater at $10-15^{\circ} \mathrm{C}$ in the turbulent than in the static treatment (DELANEY, 2003). The environmental temperature can influence this factor. The effects of turbulence have been reported as small under cold conditions (temperature less than $2^{\circ} \mathrm{C}$ ), but increase with the size of the organism (DELANEY and KNOECHEL, 2004). 


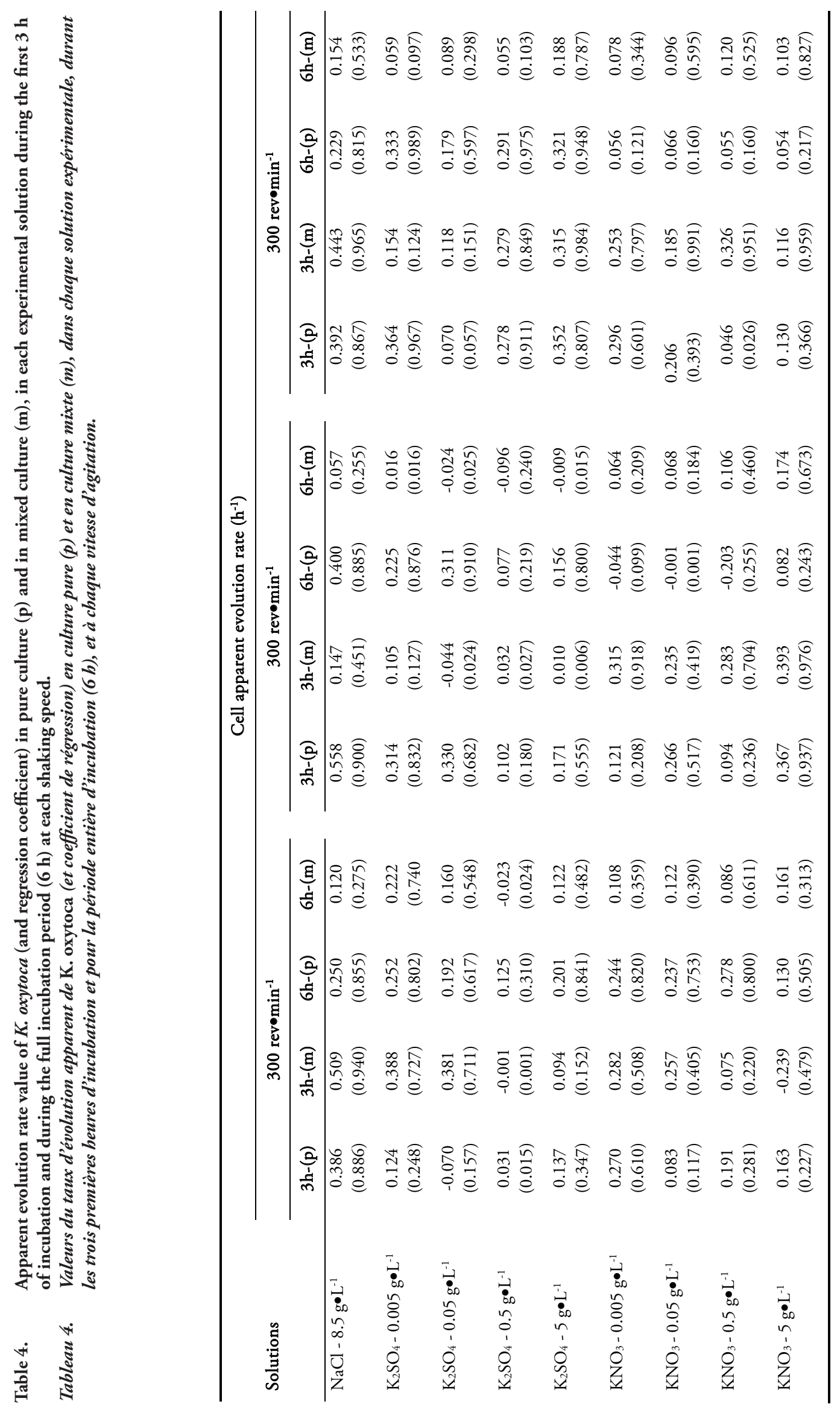


In solutions containing $\mathrm{K}_{2} \mathrm{SO}_{4}$, the negative apparent evolution rates at shaking speeds of $350 \mathrm{rev} \bullet \mathrm{min}^{-1}$ and $400 \mathrm{rev} \bullet \mathrm{min}^{-1}$ were noted in most cases when considering the full period of incubation. This would result from interactions between cells in solutions. ARAYA et al. (2003) noted in stream water that community structures in planktonic Proteobacteria, Cytophaga and Flabobacterium changed continuously with time. At some agitation speeds or some salt concentrations in the medium, the evolution rate of cell abundance of the bacterial species seems opposite. Moreover, bacterial growth rate and production of quorum-sensing inhibitors constituted an attempt to identify attributes allowing bacteria to effectively interact and coexist in a water environment. SIMOES et al. (2007), when investigating on interactions amongst most species of Methylobacterium, Sphingomonas, Burkholderia, Staphylococcus and Acinetobacter genera, noted synergy/cooperation between some species, and antagonism and neutral interactions between others, the result of interactions undergoing temporal evolution. This would be one of the origins of variations in the changing of the evolution rates of cell abundances observed in this study. Moreover, mechanical stress gave greater impact on the cells and could alter the cell internal structures and also impact the enzyme activity. It has also been indicated that the small-scale turbulence on Escherichia coli, a single-celled motile heterotroph, and Selenastrum capricornutum, a singlecelled nonmotile autotroph significantly modulates in different magnitudes the nutrient uptake and growth in comparison to still-water control; the rate of energy dissipation emerges as a physically based scaling parameter integrating turbulence across a range of scales and microscopic organism responses at the cell level (HONDZO and WUEST, 2009).

It was observed that the bacterial abundance undergone temporal fluctuations during the same shaking speed at each of the salt concentration. According to PURWANT et al. (2009), the agitation at the beginning could provide higher amounts of dissolved oxygen in the medium and might enhance the enzyme production. But for a long period, due to shear stress and forces, as well as abrasion, the cell morphology changes and the enzyme production decreases. It was noted in this study that the shapes of curves of the abundance variation of each bacterial species in pure cultures are different from those obtained in mixed cultures. This could be due to different products released in the medium by each cell species. In addition, according to STRATFOR and WILSON (1990), cells in aqueous suspensions may be regarded as colloidal. Negatively charged microbes attract positive ions from the medium, forming electric double-layers, and remain in suspension by mutual repulsion. However, many microbes form specific structures and substances with the aim of promoting interactions. These include cell-cell recognition phenomena and mating interactions. Moreover, agitation may also tear aggregates apart and cause surface damage to or disruption of individual cells. It lets out that in natural aquatic environment, the abundance evolution of a bacterial species resulted from complex processes.

\section{CONCLUSION}

At the same chemical concentration in the aquatic environment, cells are impacted by the speed of movement of the medium. The growth potential of a microbial species can be positively or negatively influenced by these chemical and physical factors, independently of other species. But in the presence of other species, the process seemed quite different.

\section{ACKNOWLEDGEMENTS}

This investigation was partially supported by the International Foundation for Science (IFS), Sweden, through research grants to Moïse NOLA (Ref.: W/4510-1).

\section{BIBLIOGRAPHICAL REFERENCES}

ARAYA R., K. TANI, T. TAKAGI, N. YAMAGUCHI and M. NASU (2003). Bacterial activity and community composition in stream water and biofilm from an urban river determined by fluorescent in situ hybridization and DGGE analysis. FEMS Microb. Ecol., 43, 111-119.

BAE H.-S., T. YAMAGISHI and Y. SUWA (2002). Evidence for degradation of 2-chlorophenol by enrichment cultures under denitrifying conditions. Microbiol., 148, 221-227.

COTTRELL M.T. and D.L. KIRCHMAN (2000). Natural assemblages of marine proteobacteria and members of the Cytophaga-Flavobacter cluster consuming low- and highmolecular-weight dissolved organic matter. Appl. Environ. Microbiol., 66, 1692-1697.

DARAH I. and C.O. IBRAHIM (1998). Laboratory-scale production of lignin-degrading enzymes by free and entrapped cells of Phanerochoete chrysosporium in a tubular air-lift bioreactor. Folia Microbiologica, 43, 161-168.

DELANEY M.P. (2003). Effects of temperature and turbulence on the predator-prey interactions between a heterotrophic flagellate and a marine bacterium. Microb. Ecol., 45, 218-25. 
DELANEY M.P. and R. KNOECHEL (2004). Turbulence effects on cold ocean microbial communities: an enclosure study. J. Mar. Sys., 49, 123-131.

DJUIKOM E., T. NJINE, M. NOLA, V. SIKATI and L-B. JUGNIA (2006). Microbiological water quality of Mfoundi river watershed at Yaounde Cameroon, as inferred from indicator bacteria of fecal contamination. Environ. Monitor. Assess., 122, 171-183.

DJUIKOM E., T. NJINÉ, M. NOLA, N. KEMKA, S.H. ZEBAZE TOGOUET and L-B. JUGNIA (2008). Significance and suitability of Aeromonas hydrophila vs.fecal coliforms in assessing microbiological water quality. World J. Microbiol. Biotechnol., 24, 2665-2670.

EL-TAYEB O., F. MOHAMMAD, A. HASHEM and M. ABOULWAFA (2007). Optimization of the industrial production of bacterial alpha amylase in Egypt. IV. Fermentor production and characterization of the enzyme of two strains of Bacillus subtilis and Bacillus amyloliquefaciens. Afr. J. Biotechnol., 7, 4521-4536.

GANDHI S., B.-T. OH, J.L. SCHNOOR and P.J.J. ALVAREZ (2002). Degradation of TCE, Cr(VI), sulfate, and nitrate mixtures by granular iron in flow-through columns under different microbial conditions. Water Res., 36, 1973-1982.

GARSTECKI T. and S.A. WICKHAM (2001). Effects of resuspension and mixing on population dynamics and trophic interactions in a model benthic microbial food web. Aquat. Microb. Ecol., 25, 281-292.

HOLT J.G., N.R. KRIEG, P.H.A. SNEATH, J.T. STALEY and S.T. WILLIAMS (2000). Bergey's manual of determinative bacteriology. LIPPINCOTT and WILKINS (Editors), Philadelphia, USA, 787 p.

HONDZO M. and A. WUEST (2009.) Do microscopic organisms feel turbulent flows? Environ. Sci. Technol., 43, 764-768.

LE MINOR L. and M. VERON (1989). Bactériologie médicale. FLAMMARION (Éditeur), Paris, France, 1107 p.

MARCHAL N., J.L. BOURDON and Cl. RICHARD (1991). Les milieux de culture: Pour l'isolement et l'identification biochimique des bactéries. DOIN (Éditeur), Paris, 509 p.

MOESENEDER M.M. and G.J. HERNDL (1995). Influence of turbulence on bacterial production in the sea. Limnol. Oceanogr., 40, 1466-1473.
PAPAGIANNI M., S.E. NOKES and K. FILER (2001). Submerged and solid-state phytase fermentation by Aspergillus niger: Effects of agitation and medium viscosity on phytase production, fungal morphology and inoculum performance. Food Technol. Biotechnol., 319, 39-326.

PINAR G. and J.L. RAMOS (1998). Recombinant Klebsiella oxytoca strains with improved efficiency in removal of high nitrate loads. Appl. Environ. Microbiol., 64, 5016-5019.

PINHASSI J., S.M. MONTSERRAT, H. HAVSKUM, F. PETERS, O. GUADAYOL, A. MALITS and C. MARRASE (2004). Changes in bacterioplankton composition under different phytoplankton regimens. Appl. Environ. Microbiol., 70, 6753-6766.

PORCEL E.M.R., J.L.C. LOPEZ, J.A.S. PEREZ, J.M.F. SEVILLA and Y. CHISTI (2005). Effects of pellet morphology on broth rheology in fermentations of Aspergillus terreus. Biochem. Eng., 26, 139-144.

PURWANT L.A., D. IBRAHIM and H. SUDRAJAT (2009). Effect of agitation speed on morphological changes in Aspergillus niger hyphae during production of tannase. World J. Chem., 4, 34-38.

REIS M.A.M., J.S. ALMEIDA, P.C. LEMOS and M.J.T. CARRONDO (2005). Effect of hydrogen sulfide on growth of sulfate reducing bacteria. Biotechnol. Bioeng., 40, 593-600.

ROCKNE K.J., J.C. CHEE-SANFORD, R. SANFORD, B. HEDLUND, J.T. STALEY and S.E. STRAND (1999). Naphthalene degradation and mineralization by nitratereducing and denitrifying pure cultures. In-Situ On-Site Bioremediation, 5, 271-276.

RODIER J. (1996). L'analyse de l'eau. DUNOD (Éditeur), Paris, France, 1384 p.

SEKOWSKAA. and A. DANCHIN (2009). Sulfur metabolism in bacteria, with emphasis on Escherichia coli and Bacillus subtilis. http://www.pasteur.fr/recherche/unites/REG/ sulfur_review.html (accessed 23/02/2009).

SIMOES L.C., M. SIMOES and M.J. VIEIRA (2007). Biofilm interactions between distinct bacterial genera isolated from drinking water. Appl. Environ. Microbiol., 73, 6192-6200.

STRATFOR M. and D.P.D.G. WILSON (1990). Agitation effects on microbial cell-cell interactions. Lett. Appl. Microbiol., 11, 1-6. 
TALON R., D. WALTER, S. CHARTIER, C. BARRIERE and M.C. MONTEL (1999). Effect of nitrate and incubation conditions on the production of catalase and nitrate reductase by staphylococci. Int. J. Food Microbiol., $52,47-56$.

TRIPP H.J., J.B. KITNER, M.S. SCHWALBACH, J.W.H. DACEY, L.J. WILHELM and S.J. GIOVANNONI (2008). SAR11 marine bacteria require exogenous reduced sulphur for growth. Nature, 452, 741-744.

WHO (2003). Global Water Supply and Sanitation Assessment 2000 Report. http://www.who.int/docstore/watersanitation-health/globassessment (accessed 17/11/2008).

WU Q. and V. STEWART (1998). NasFED proteins mediate assimilatory nitrate and nitrite transport in Klebsiella oxytoca (pneumoniae) M5al. J. Bacteriol., 180, 1311-1322.

ZHAO X., J. DUAN, B. HOU and S. WU (2007). Effect of sulfate-reducing bacteria on corrosion behavior of mild steel in sea mud. J. Mater. Sci. Technol., 23, 323-328.

ZINEBI S., G. RAVAL and H. PETITDEMANGE (1994). Effect of oxygenation and sulfate concentrations on pyruvate and lactate formation in Klebsiella oxytoca ZS growing in chemostat cultures. Current Microbiol., 29, 79-85. 